\title{
Crowdfunding And Social Networks In The Music Industry: Implications For Entrepreneurship
}

Ricardo Martínez-Cañas, University of Castilla-La Mancha, Spain Pablo Ruiz-Palomino, University of Castilla-La Mancha, Spain Raúl del Pozo-Rubio, University of Castilla-La Mancha, Spain

\begin{abstract}
With the development of new communication technologies and the unstoppable increase of social networks some microfinance platforms are becoming essential tools for entrepreneurs. This phenomenon is known as "crowdfunding", "crowdfinancing" or "crowd sourced capital", what mainly implies that entrepreneurs obtain the funds or capital through a collective cooperation usually via a web platform. For social networks this process is based on the trust of many promoters and communities of interest that pool together their money for supporting projects or initiatives. Despite these crowdfunding activities occurs for any variety of purposes as different as political campaigns or creating open source software in this paper we are going to focus on the role for music industry. For musicians and music promoters crowdfunding is being used as a mechanism for putting into the market their creative work (records, video clips, concerts and other promotional releases. Therefore, in this paper we are going to study the origins, concept, and models to finally show an example for the music industry analyzing the concrete case of a well-known Spanish platform.
\end{abstract}

Keywords: Crowdfunding; Social Capital; Social Networks; Music Industry; Entrepreneurship

\section{INTRODUCTION}

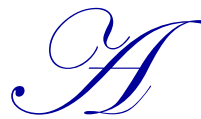

ccording to McMillan Web-Dictionary crowdfunding can be defined as "the use of the web or another online tool to get a group of people to finance a particular project"1. In that sense is based in a broad related concept known as "Crowdsourcing" what reflects the act of taking a task traditionally performed by a designated agent (such as an employee or a contractor) and outsourcing it by making an open call to an undefined but large group of people interested in collaborate (Howe, 2009). Therefore, crowdsourcing allows the power of the crowd to accomplish tasks that were once the province of just a specialized few (Howe, 2009). If we focus on the monetary aspects of the crowd we are focusing on the collective cooperation for obtain funds, capital, money and other resources, usually via a web platform, to support efforts and projects initiated by other people or organizations (Ordanini et al, 2011). In that sense, crowdfunding occurs for any variety of purposes related with microfinance activity from journalism, to artists seeking support from fans, to funding a startup company, for shooting a movie, for starting up a small business or for creating an open source software program (Lawton \& Maron, 2010).

From the early beginning, the productive use of crowd power is not merely limited to ranking things (Howe, 2009). People can also come together to pool their money and do interesting things (Roebuck, 2011). Some examples of this kind of joint activities are web-platforms such as Kiva.org that connects small businesses in Third World countries with lenders located in First World countries who are philanthropically minded. Another example is the British Web site MyFootballClub.co.uk that has collected 35 pounds from fifty thousand people in order to

\footnotetext{
${ }^{1}$ http://www.macmillandictionary.com (retrieved on $15^{\text {th }}$ of January, 2012)

(C) 2012 The Clute Institute http://www.cluteinstitute.com/
} 
purchase a professional football team. By November 2007, more than 700,000-pounds had been raised and the Ebbsfleet United Football Club was acquired. Today, this platform is using online voting to decide everything from what the team wears to who should coach the team and which players the club should contract.

For the media industry, the origin of this kind of funding tool for entrepreneurs is based in the support of music bands through a fan-based internet campaign (Lawton \& Maron, 2010). During the 1990s this idea was conceived and managed by fans without any involvement of bands and was a starting point with a great success for marketing and recording activities (Roebuck, 2011). In the United States was documented the first crowdfunding company in the music industry named ArtistShare in 2000 and was rapidly followed by other web platforms such as Sellaband in 2006, IndieGoGo in 2008 and Kickstarter in 2009). In UK have emerged Sponsume in 2010 and PleaseFund.Us in 2011. In Spain since 2010 platforms such as Verkami and Goteo.org are supporting all kind of entrepreneurial related projects.

In this paper, first we identify the different kind of existing crowdfunding platforms that mainly are related with reward-based, equity-based or micro-finance models. In the third paragraph we use a descriptive study of the Spanish crowdfunding platform to illustrate the crowdfunding process. Finally, some conclusions and practical implications for entrepreneurs are showed.

\section{CROWDFUNDING PLATFORMS}

With the development of crowdfunding platforms, there is an exponential increase of intermediary services that have emerged to act as the interface between the public and the proposed projects (Schiwienbacher \& Larralde, 2010). The main aim of these platforms is the facilitation of transactions through their knowledge, knowhow and previous experience that is the value they add for some artists, creators and entrepreneurs (Roebuck, 2011). In that sense, they are reducing the transaction costs and law complexity that is inherent in market. Therefore these platforms are spreading the project to new audience with effective and successful campaigns with social networks tools like Facebook or twitter.

Crowdsourcing website (http://www.crowdsourcing.org) has proposed a classification for platforms by the type of return promoters will get: rewards, equity or micro-credit. The first one, the reward-based model it is when promoters make a donation of money to a project with the expectation of a reward (material or in-material). This is the most accepted model so far and has two main sub-models: the first and more prominent is the "all-or-nothing model" where entrepreneurs target a sum of money that must be complete reached within a pre-arranged period of time, and where if the target is not reached there is no financial transaction and promoters credit card is not charged, and second, the "keep it all" model where funds are paid immediately to the project and entrepreneurs keep all the money they raise even if the target is not met.

The second model is an equity-based one, because platforms define a period of time where a target is divided into equal shares which are offered via the platform as equity shares at fixed prices. It also has two submodels, the first one is "the club model" where potential promoters are recruited using a closed "investment club" that is not offered to the public directly and the second one is the "cooperative model" where the platform act as cooperative where promoters contribute and take decisions with the system of "one person one vote".

The last model, the micro-finance is when the platform is offering a provision of financial services trough microlending to entrepreneurs with lack of access to the banks and traditional systems. It also has two differentiated models, the first one is based in the "microlending supporting" where provide funds for low-income clients, customers and self-employed entrepreneurs. And the second sub-model is based in a "peer to peer" lending system that occurs directly between individuals without the intermediation of a traditional financial institution.

\section{THE CASE OF VERKAMI}

As a descriptive case for exemplifying the crowdfunding phenomenon we use the Spanish firm Verkami. This company was created in December 2010 as a financial go-between for supporting mainly artist and all kind of cultural entrepreneurs. His supporting role is mainly act as a crowdfunding platform website where "many patrons 
get together to make small individual contributions to finance original and innovative ideas by creators, entrepreneurs, promoters and organizations" ${ }^{2}$.

Verkami was physically created in the city of Mataró (near Barcelona) for a family (a father and his two sons) with different cultural backgrounds and a common passion for creativity, art and research. The word Verkami is a neologism created by putting together two words in Esperanto language: "Verko": (artistic creation or scientific; work; production) or in its verb form verki: (to create artistic or scientific works; to produce art) and "Ami": love, like, and that etymologically comes from the word "friend". So the meaning of Verkami is: "a friend of creation".

Their philosophy is to be an open web platform for financing artists and cultural entrepreneurs giving them the complete ownership of their project. His idea is that the patrons or donators will receive great rewards (products, services or exclusive experiences) in return of their money. In that sense of ownership, their contribution to a project is not the same as investing in it.

As an open to publish web anyone with a good idea can start a project. Therefore not only artists and entrepreneurs are interested in this platform also it is an interesting tool for promoters and associations to organize events such as concerts or exhibitions. The most active projects financed and supported are related to topics such as: films, music, video clips, media development, theatre, comics, community projects, design, software, photography, technology, social endeavours, journalism and literature. From a risk point of view, this company is adding value for firms in the sense that it is a good way of testing how popular or successful a project might be without suffering from a high monetary investment, because if a project doesn't have enough supporters maybe the artist will need to change the focus.

\section{The" all or nothing" funding system}

The company is using a funding system where every project has a funding goal that must be reached in less than 40 days. Once the time has expired there are two kind of possible scenarios:

1) The project is successfully funded and consequently patrons' card will be charged when the project reaches its funding deadline. It also can be possible that a project can reach his funding goal before the deadline what is better for the artist that can keep on raising funds till the 40 days period is over.

2) The project is not successfully funded. The patrons' contribution is cancelled, their card is never charged. In that case, the entrepreneurs can't receive the \% of money raised because to complete the project they need the $100 \%$ they wanted to achieve. So in that situation is a good thing to rethink about idea, description, money needed, and rewards offered to patrons, levels of contribution and so on.

\section{The quality management in the process}

After the entrepreneur registration in the system and once he has filled the form with all the interesting aspects his project is offering, the Verkami administrators carefully review in deep the project asking for more precise details. A project can be any idea that the artist or entrepreneur can come up with. All projects that might be offensive, violent or illegal are rejected. Normally this process is taking about 10 days to be approved or rejected. All projects must be reviewed in order to supports quality projects that are highly creative and innovative and rejecting other projects that don't fulfil a minimum quality criteria. During the checking process the Verkami team has the opportunity to give to the entrepreneur a quality feedback in order to make his project in a clear and attractive way.

The Verkami team helps the entrepreneur to advise the entrepreneur about the key aspects he must know: how to calculate the funding goal, to determine how many levels of contributions and the rewards to give to the patrons in return. The entrepreneur has a personal page/blog that can manage and modify some aspects of their project (photos, videos, colours, text and so on). It also has an interactive tool for questions and answers where they try to solve doubts for their patrons and receive valuable feedback. Creators also receive help for promoting their

\footnotetext{
${ }^{2}$ Crowdfunding definition supported by Verkami in his website: http://www.verkami.com

C 2012 The Clute Institute http://www.cluteinstitute.com/
} 
project in social networks. Finally, and once the project is approved Verkami will set up all details of your projects in the web platform and the entrepreneur can begin fundraising.

\section{The business model}

The business model of Verkami is mainly based in a fee system. The firm charges a $5 \%$ fee to entrepreneurs due its services over the funding goal total amount. This fee is applicable only if your project is successfully funded. If it's not, they don't charge any money. Verkami is assuming the risk of the unsuccessful projects because they don't receive any money for publishing and promoting the project. So a key aspect in his business model is how to calculate the budget for the entrepreneur. This budget it must reflect the money for the project and also other important things such as: the Verkami 5\% fee, the cost of the rewards, the cost of delivering them, account taxes, bank fees, etc.

\section{Key numbers of Verkami}

- $\quad$ First crowdfunding platform in Spain

- $\quad$ The minimum funding goal of Verkami is $800 €$ and they don't have any maximum.

- $\quad$ Rewards depend on contributions. (Different levels). Usually uses the system of "a higher contribution get a higher reward"

- $\quad$ The level of contributions can range from $5 €$ to $5000 €$.

- $\quad$ Patrons make their contributions by credit card after the 40 days period.

- $\quad$ Bank charges to the artist a transaction fee (between 1.30-1.45\%) for each contribution.

- $\quad 0 \%$ is the percentage of ownership or intellectual property of the projects published that take Verkami. So creators keep $100 \%$ ownership of their work.

- The project is $100 \%$ interactive, because the more creators make patrons part of the creative process, the more they'll feel like the project is their own, and the more they'll help to promote it.

\section{Main results after 18 months}

Verkami has supported during the period from December 2010 till April 2012 over 350 projects (of all kinds) were financed successfully. Focusing on music related projects such as concerts, video clips, album recordings and other musical events there were financed 158 projects. Despite there are no "official" results of their activity we have collected some financial results and a few statistics of their activity within music industry:

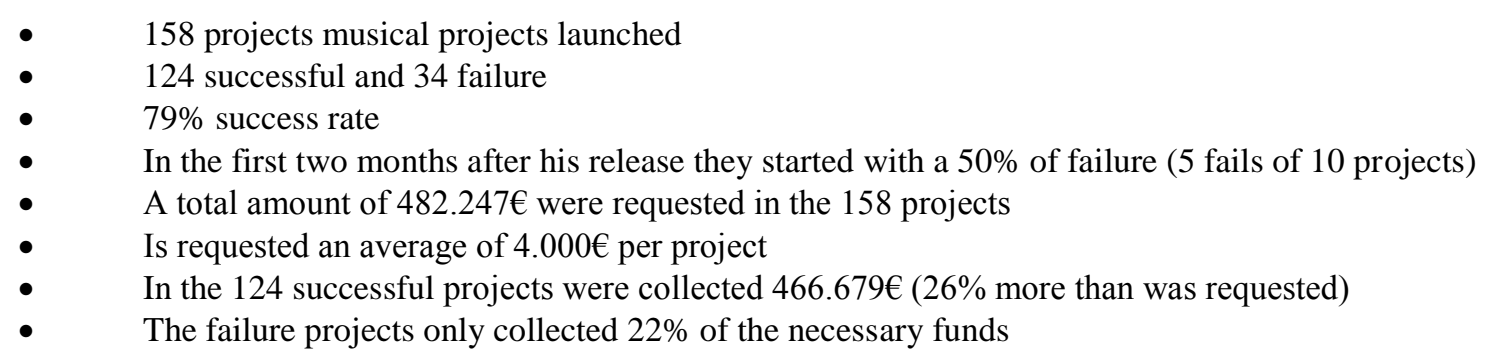

\section{CONCLUSIONS AND IMPLICATIONS FOR ENTREPRENEURS}

To conclude, it is clear that crowdfunding activities allow entrepreneurs to have several advantages such as access to funds, avoid finantial risk, overcome the liability of newness, identify the real target audience of a start-up and mainly it can be a trampoline system for higher expectative with low amount of money.

As the main disadvantages for entrepreneurs are to make public their ideas in the market and rivals could copy. In recent times there are a lot of problems with property rights and patents. Also, it cannot be a good idea if the entrepreneur needs an important quantity of money and the crowdfunding effect could fade in a few months. Therefore, this activity has the risks of web 2.0 and social networks whose effect is still not clear and sometimes is overrated. 
Finally, this descriptive study can show some implications, the first and more important for future entrepreneurs is the process of choosing the right platform, that is a very important step in a crowdfunding (as we have shown each platform has a specific value). Know the attractive of your project. It can be a participative project because it can grow with the feedback of your finantial supporters. Motivation for your stakeholders

\section{AUTHOR INFORMATION}

Ricardo Martinez-Cañas is an Associate Professor of Business Administration at UCLM (University of Castilla-La Mancha, Spain). He is a Ph.D. in Business Administration by UCLM and his current research interests are focused on business ethics, Social Capital and Social Networks. E-mail: Ricardo.Martinez@uclm.es (Corresponding author)

Pablo Ruiz-Palomino is an Associate Professor of Business Administration at UCLM. He is a Ph.D. in Business Administration and his current research interests are focused on business ethics and Social Capital. E-mail: Pablo.Ruiz@uclm.es

Raul del Pozo-Rubio is an Assistant Professor of Finance Department at UCLM. He is a doctoral candidate and his current research interests are focused on long term care costs and financing as well as tourism and environment. E-mail: Raul.delpozo@uclm.es

\section{REFERENCES}

1. Howe, J. (2009). Crowdsourcing: Why the Power of the Crowd Is Driving the Future of Business. New York: Crown Business Editors.

2. $\quad$ Ordanini A., Miceli L., Pizzetti M. \& Parasuraman A. (2011). Crowd-Funding: Transforming Customers into Investors through Innovative Service Platforms, Journal of Service Management 22(4), 443-470.

3. Lawton, K \& Maron, D. (2010). The Crowdfunding Revolution: How to Raise Venture Capital Using Social Media. San Francisco: Mc-Graw Hill.

4. Roebuck, K. (2011). Crowdfunding: High-Impact Strategies - What You Need to Know: Definitions, Adoptions, Impact, Benefits, Maturity and Vendors. London: Teboo Publishing.

5. Schwienbacher, A. \& Larralde, B. (2010). Crowdfunding of Small Entrepreneurial Ventures. In Cumming, D. (Ed) The Oxford Handbook of Entrepreneurial Finance, Oxford University Press, pp. 369-391. 


\section{NOTES}

